\title{
PERANAN PENGENDALIAN TATA USAHA UNTUK MENUNJANG KELANCARAN TUGAS DI SDN I WAY GUBAK KECAMATAN PANJANG KOTA BANDAR LAMPUNG
}

\author{
Oleh \\ Fajar Mutia Suri ${ }^{1}$ \\ Fera Wati ${ }^{2}$ \\ Program Studi Administrasi Bisnis, Universitas Tulang Bawang Lampung \\ e-Mail: fajarinsky18@yahoo.com
}

\begin{abstract}
ABSTRAK
Usaha untuk meningkatkan kelancaran tugas harus dilaksanakan, salah satu cara yang dapat ditempuh adalah dengan pengendalian tata usaha dalam menjalankan tugas sehingga dapat menunjang kelancaran tugas. Atas dasar uraian di atas, penulis mengadakan penelitian untuk mengetahui peranan pengendalian tata usaha untuk menunjang kelancaran tugas SDN 1 Way Gubak Kecamatan Panjang Kota Bandar Lampung.

Dalam melaksanakan penelitian penulis menggunakan metode deskriptif yaitu menjajaki suatu fenomena atau gejala dan kenyataan, berkenaan dengan masalah yang diteliti. Pemaparan hasil penelitian didukung dengan pendistribusian data kedalam bentuk tabel dan rumus-rumus yang penulis gunakan. Dipertanggungjawabkan secara ilmiah, maka teknik pengumpulan data yang dilakukan melalui penelitian kepustakaan dan penelitian yang dilakukan langsung terjun dilapangan terhadap objek dan sasaran yang diteliti dengan cara observasi, wawancara, dokumentasi serta kuisioner.

Berdasarkan hasil penelitian dan pembahasan yang penulis lakukan terhadap data dan informasi yang diperoleh, bahwa peran pengendalian tata usaha SDN 1 Way Gubak Kecamatan Panjang Kota Bandar Lampung adalah dalam kategori baik. Demikian juga halnya keadaan kelancaran tugas dalam kategori baik. Selanjutnya berdasarkan hitungan dengan menggunakan rumus statistik korelasi produk moment diperoleh nilai $r_{\text {hitung }}=0,621$. Sedangkan perhitungan menggunakan uji $t$, diperoleh nilai $t_{\text {hitung }}$ sebesar 2,505. Setelah dikonsultasikan pada nilai tabel dengan derajat kebebasan n-2 (12-2) dan derajat penyimpangan (alpa) 5\% $(0,05)$ diperoleh nilai 1,812. Hal ini berarti $t$ hitung lebih besar dari $t$ tabel, dengan demikian hipotesis penulis peran pengendalian tata usaha berjalan efektif dalam menunjang kelancaran tugas SDN 1 Way Gubak Kecamatan Panjang Kota Bandar Lampung diterima.
\end{abstract}

Kata kunci: pengendalian, tata usaha, kelancaran tugas

\section{PENDAHULUAN}

A. Latar Belakang

Konsep pembangunan yang baik serta didukung oleh alokasi dana yang cukup, memungkinkan terlaksananya suatu keberhasilan pembangunan.Namun apabila pelaksanaannya tidak mampu melaksanakannya dengan baik,maka tentu tidak akan mencapai suatu hasil yang 
maksimal. Karena itu sangatdiperlukan peran serta dan kesempurnaan suatu Aparatur Negara, dalam halini Pegawai Tata Usaha juga berperan aktif dalam meningkatkan kelancarantugas yang dijalankan pada kantor-kantor atau organisasi tertentu dalampelaksanaan pembangunan nasional.

Untuk membentuk suatu organisasi kerja yang baik dan membentukAparatur Negara yang sempurna sebagai penyelenggara dan pelaksanapembangunan, maka diperlukan tahap-tahap kerja yang sesuai dengankemampuan, keahlian, dan keterampilan kerja pegawai dalam menjalankantugasnya, agar mencapai hasil yang maksimal, efektif, efisien, berwibawa,serta bertanggung jawab terhadap bangsa dan negara.

Dalam rangka pembangunan manusia seutuhnya yang berarti bahwapembangunan tidak hanya mengejar kemajuan lahiriah dan kepuasan batinmelainkan keseimbangan, keselarasan, dan keserasian antara keduanya, makadilaksanakan pembangunan nasional yang merupakan suatu proses perubahan.

Sosial secara berencana untuk menjadikan manusia sebagai obyek dan sekaligus sebagai subyek dalam pembangunan. Suatu usaha kegiatan pembangunan harus dimanfaatkan sebesarbesarnya bagi kehidupan manusia seutuhnyn yang berdasarkan Pancasila dan Undang-Undang Dasar 1945.

Pola Dasar Pembangunan Nasional menggerakkan apa yang menjaditujuan Pambangunan Nasional, yang tidak lain adalah penegasan terhadapcita-cita bangsa seperti yang terkandung dalam UndangUndang Dasar 1945, pembinaan Aparatur Pemerintah diarahkan agar mampu melaksanakan tugas-tugas umum pemerintah maupun untuk menggerakkan dan memperlancar pelaksanaan pembangunan.

Peranan pegawai tata usaha sebagai Aparatur Negara merupakan salah satu penyelenggara pembangunan perlu diperhatikan dan dibina agar dapat meningkatkan kemampuannya untuk menuju suatu kesempurnaan, sehingga di dalam menjalankan tugas dapat berjalan dengan baik dan sempurna sesuai dengan harapan dan apa yang telah ditentukan.

Untuk itu usaha-usaha penerbitan dan penyempurnaan aparatur yang meliputi baik struktur, prosedur kerja, maupun sarana dan fasilitas kerja perlu dilakukan terus menerus, sehingga keseluruhan Aparatur Pemerintah baik ditingkat pusat maupun ditingkat daerah benar-benar merupakan alat yang berwibawa, bertanggung jawab, kuat, efektif, efisien, dan bersih penuh wibawa, kesetiaan atau ketaatan kepada negara dan pemerintah serta diisi oleh tenaga ahli, mampu menjalankan tugas dibidang masing-masing dan hanya mengabdikan diri kepada kepentingan negara dan masyarakat.

Diantara kemampuan personil yang diharapkan untuk dimiliki oleh setiap pendukung Aparatur Pemerintahan adalah kemampuan dalam memberikan informasi dengan baik dan benar.

Pada SDN 1 Way Gubak Kecamatan Panjang Kota Bandar Lampung dalam proses pembuatan kebijaksanaan belum sepenuhnya memenuhi unsur-unsur ketatausahaan, sehingga kebijaksanaan itu belum dapat diputuskan sesuai dengan tujuan organisasi itu sendiri. Hal inilah yang mendorong penulis tertarik untuk mengambil judul skripsi : Peranan Pengendalian Tata Usaha Untuk Menunjang Kelancaran Tugas SDN 1 Way Gubak Kecamatan Panjang Kota Bandar Lampung. 


\section{B. Tujuan Penelitian}

Setiap kegiatan sudah barang tentu mempunyai tujuan, demikian juga penelitian yang penulis lakukan pada SDN1 Way Gubak Kecamatan Panjang Kota Bandar Lampung.

Adapun yang menjadi tujuan dalam penelitian ini antara lain adalah :

1. Tujuan Penelitian

a. Ingin mengetahui bagaimana peran pengendalian tata usaha dalam menunjang kelancaran tugas SDN1 Way Gubak Kecamatan Panjang Kota Bandar Lampung.

b. Ingin mengetahui apakah peran pengendalian tata usaha berjalan efektif dalam menunjang kelancaran tugas SDN1 Way Gubak Kecamatan Panjang Kota Bandar Lampung.

\section{Kegunaan Penelitian}

a. Diharapkan sebagai sumbangan pemikiran dalam hal mendorong peran pengendalian tata usaha untuk menunjang kelancaran tugas SDN1 Way Gubak Kecamatan Panjang Kota Bandar Lampung.

\section{LANDASAN TEORI}

\section{A. Kearsipan dan Tata Usaha}

Setelah penulis kemukakan pengertian administrasi dan organisasi tersebut diatas maka selanjutnya penulis kemukakan tentang pengertian arsip sebagai salah satu tugas daripada kegiatan tata usaha. Administrasi kearsipan sebagai bagian dari Administrasi perkantoran yang dijalankan oleh tata usaha kantor sangat penting dalam membantu tugas para karyawan/pegawai.
Kegiatan-kegiatan yang termasuk dalam kearsipan itu antara lain kegiatan yang berkenaan dengan penerimaan, pencatatan, pengiriman, penyingkiran, maupun pemusnahan surat menyurat atau berbagai macam dokumen lainnya. Dibawah ini penulis mengutip pendapat beberapa sarjana yaitu:

Menurut Drs. The Liang Gie, Arsip adalah kumpulan daripada surat-surat yang terjadi oleh karena pekerjaan aksi transaksi, tindak tanduk, dokumenter (dokumentaire handeling), yang disimpan sehingga pada tiap-tiap saat dibutuhkan dapat dipersiapkan, untuk melaksanakan tindakan-tindakan selanjutnya. (1999:216)

Sedangkan menurut Komarudin, arsip adalah proses penyusunan dan penyimpanan dokumen asli atau copy-nya, sehingga dengan cara itu maka dokumen tersebut dapat ditemukan dengan mudah jika diperlukan. (1991:207)

Dalam pelaksanaan tata usaha pada semua kantor banyak sekali dipergunakan kertas dan peralatan tulis yang beraneka ragam. Oleh karena itu pekerjaan tata usaha sering disebut pekerjaan tulis menulis.

Dengan dilakukannya pekerjaan tersebut pada setiap kantor untuk mencatat berbagai informasi pada lembaran kertas maka terciptalah arsip atau dokumen, Dokumen adalah setiap cacatan tertulis atau bergambar yang memuat keterangan mengenai sesuatu hal atau peristiwa yang dibuat orang untuk membantu ingatannya.

Berdasarkan uraian tersebut diatas,maka pada dasarnya tata usaha bersangkut paut dengan arsip/dokumen. Fungsi pokok tata usaha dapat diringkas menjadi kegiatan-kegiatan membuat dokumen dan menyimpan dokumen.

Jadi kegiatan menyimpan keteranganketerangan sebagai suatu aktivitas tata 
usaha dalam kenyataannya berupa menaruh dokumen dengan berbagai cara dan alat ditempat tertentu yang aman agar tidak rusak atau hilang.

Pengertian arsip jika dilihat dari sudut fungsinya dapat dibedakan menjadi arsip dinamis dan arsip statis.

a. Arsip Dinamis adalah arsip yang masih dipergunakan secara langsung dalam penyusunan perencanaan, pelaksanaan kegiatan pada umumnya dan pelayanan ketatausahaan. Berdasarkan nilai yang senantiasa berubah yang dipakai untuk kriteria arsip dinamis, sebenarnya arsip dinamis dapat dirinci lagi menjadi:

1) Arsip aktif, yaitu arsip yang masih dipergunakan terus menerus bagi kelangsungan pekerjaan dilingkungan unit pengolahan dari suatu organisasi.

2) Arsip semiaktif, yaitu arsip yang frekuensi penggunaannya sudah mulai menurun.

3) Arsip inaktif,yaitu arsip yang tidak lagi dipergunakan secara terus menerus,atau frekuensi penggunaannya sudah jarang atau hanya dipergunakan sebagai referensi saja.

b. Arsip Statis

Adalah arsip yang tidak dipergunakan secara langsung dalam perencanaan, penyelenggaraan kegiatan maupun untuk penyelenggaraan pelayanan ketata usahaan dalam rangka penyelenggaraan kehidupan kebangsaan ataupun untuk penyelenggaraan sehari-hari administrasi negara. Arsip ini tidak lagi berada pada organisasi pencipta arsip tersebut akan tetapi berada di Arsip Nasional Indonesia. Untuk menjalankan fungsi tersebut dengan baik,maka petugas tata usaha dalam penataan arsip mempunyai kewajiban :

1) Penyimpanan berkas surat dinas

2) Pemeliharaan dan pengendalian berkas surat dinas

3) Penyusunan dan pemusnahan berkas surat dinas yang sudah tidak diperlukan lagi

4) Penemuan kembali berkas surat dinas yang disimpan

Jadi dapat disimpulkan bahwa yang dimaksud dengan arsip dinamis adalah arsip yang masih aktif digunakan dalam proses kerja sehari-hari, sedangkan arsip statis adalah arsip yang sudah tidak aktif dipergunakan dalam proses kerja sehari-hari.

\section{B. Sistem Kearsipan dan Fasilitas Kearsipan}

1. Sistem Kearsipan

Menurut The Liang Gie (1981 : 2931). Aktivitas pokok dalam bidang kearsipan berupa penyimpanan dokumen. Dokumen-dokumen itu harus disimpan menurut suatu sistem yang memungkinkan, penemuan kembali dengan cepat apabila diperlukan.

Dalam sistem kearsipan dikenal 5 (lima) macam sistem penyimpanan arsip, yaitu sebagai berikut :

a. Penyimpanan menurut sistem abjad (Alphabetical filing system). Suatu sistem penyimpanan dan penemuan kembali arsip berdasarkan abjad. Dalam sistem ini semua arsip/dokumen diatur berdasarkan abjad nama orang, 
organisasi atau kantor. Abjad yang dijadikan dasar kode adalah abjad pertama dan unit pertama dari suatu nama dan atau judul, Berdasarkan kebiasaan, dalam sistem abjad diambil dari abjad pertama/nama si pengirim atau si penerima surat.

b. Penyimpanan menurut sistem pokok soal (Subject filing system) Dalam sistem ini semua naskah/dokumen disusun dan dikelompokkan berdasarkan pokok masalah. Arsip/dokumen mengenai masalah yang sama ditempatkan dalam satu atau lebih folder/map yang sudah diberi label yang bertuliskan judulnya dan terletak dikanan atas secara harizontal. Misalnya semua surat yang mengenai iklan dikumpulkan menjadi satu dibawah judul iklan.

c. Penyimpanan menurut sistem nomor/angka (numerical filing system) Dalam sistem ini, dokumen yang mempunyai nomor disimpan menurut Komor urut dari satu hingga bilangan yang lebih besar.

Misalnya : Faktur-faktur yang dibuat oleh perusahaanperusahaan. Dan yang dijadikan kode di surat adalah kode yang ditetapkan sendiri oleh unit organisasi yang bersangkutan.

d. Penyimpanan menurut sistem Wilayah/dacrah (geographical filing system)

Surat-surat yang harus dipelihara oleh organisasi dapat pula disimpan menurut pembagian wilayah asal surat/dokumen. Cara ini menghendaki setiap surat yang berasal dari daerah yang sama, disimpan pada tempat yang sama pula.

e. Penyimpanan menurut sistem tunggal (Chronological filing system) Sistem ini menurut urutan tanggal yang tertera ditiap dokumen tersebut. Hal ini dijadikan penunjuk pokok adalah tahun, bulan, dan tanggal sistem dapat dipakai bagi dokumen yang harus memperhatikan sesuatu jangka waktunya tertentu, misal Mengenai surat tagihan.

Diantara kelima sistem ini tidak ada yang lebih baik atau lebih buruk dari yang lainnya, baik atau buruknya sistem tersebut tergantung pada tepat atau tidaknya penggunaan dari sistem itu sendiri.

Jadi kegiatan menyimpan keterangan sebagai suatu aktivitas tatausaha dalam kenyataannya berupa kegiatan menaruh dokumen dengan berbagai cara dan alat di tempat tertentu yang aman agar tidak rusak dan hilang, dengan dilakukannya aktivitas penyimpanan dokumen itu maka dalam Suatu organisasi terdapatlah suatu pusat ingatan dalam sumber informasi yang akan melancarkan kehidupan dan perkembangan Organisasi itu sendiri. Berbagai keterangan dalam dokumen yang disimpan itu dapat mempunyai kegunaan sangat penting untuk bahan penilaian atau penyusunan program kantor/organisasi yang bersangkutan. karena 
dokumen-dokumen yang berguna sangat penting bagi setiap organisasi apapun karena perannya sebagai alat pengingat itu.

2. Fasilitas Kearsipan.

Dalam kamus administrasi, fasilitas diartikan sebagai kebutuhan yang diperlukan untuk penyelesaian pekerjaan-pekerjaan dalam suatu usaha kerjasama manusia. Fasilitas kearsipan dapat dikelompokkan menjadi 4 golongan, yaitu :

a. Alat-alat korespondensi, seperti kertas, komputer, masin tik, mesin stensil, stempel karbon dsb.

b. Alat-alat penerimaan surat seperti bak/kotak surat, meja tulis, rak, dsb.

c. Alat-alat penyimpanan surat (setelah diarsipkan) seperti map order, folder, lemari, filing cabinet, dan sebagainya.

d. Alat-alat lainnya seperti ruangan yang cukup cahaya, kode pokok soal dan lain sebagainya.

Kebutuhan fasilitas kearsipan antara satu kantor dengan kantor laianya tidaklah sama, tergantung pada sistem apa yang digunakan. Demikian pula kebutuhan memenuhi fasilitas tidaklah sama, sehingga ada kantor yang memiliki alat-alat kearsipan yang lengkap dan ada juga yang tidak lengkap. Alat-alat kearsipan yang lengkap akan memberikan manfaat sebagai berikut :

a. Menjamin arsip dari bahaya kebakaran dan pencurian.

b. Menjamin keawetan atau tahan arsip. c. Menjamin kesehatan pegawai kearsipan

d. Menjamin kelancaran kerja, ketetapan sistem kearsipan.

e. Memelihara ketekunan atau penampung peningkatan volume kerja kearsipan

f. Memelihara ketekunan atau semangat kerja pegawai kearsipan.

\section{Pengertian Tata Usaha}

Dalam kehidupan sehari-hari sering di jumpai istilah tata usaha, dan tata usaha ini umumnya dilaksanakan di kantor-kantor instansi pemerintah, sekolah-sekolah, perusahaan negara, maupun swasta serta organisasiorganisasi kemasyarakatan lainnya. Tata usaha sering disebut administrasi dalam arti sempit yaitu yang berkaitan dengan pekerjaan catatmencatat.

Hubungan antara tata usaha dengan administrasi adalah bahwa tata usaha ialah salah satu unsur administrasi, tata usaha bukanlah merupakan aktivitas yang berdiri sendiri, melainkan turut membantu melancarkan pekerjaan pokok, sehingga apa yang menjadi tujuan suatu kerjasama kelompok orang itu dapat tercapai secara efektif dan efisien.

Agar supaya pelaksanaan tata usaha dapat berjalan dengan sebaikbaiknya, maka tata usaha perlu di tata, yaitu direncanakan, diatur, disusun, diurus, ditertibkan, dikendalikan, dan disempurnakan.

Pengertian tata usaha menurut The Liang Gie adalah segenap rangkaian aktivitas menghimpun, mencatat, mengadakan, mengolah, mengirim, menyimpan keteranganketerangan yang diperlukan dalam setiap Usaha kerjasama (2002: 52) 
Sedangkan menurut Soekamo K adalah segenap kegiatan yang meliputi tulis menulis, mengetik, korespondensi, kearsipan dan sebagainya (2005:8)

Jika penulis perhatikan pada objek penelitian, maka tata usaha mempunyai peranan penting bagi kelancaran dan tercapainya tujuan secara efektif dan efisien.

\section{Kedudukan dan Fungsi Tata Usaha} Dalam Organisasi

Walaupun kedudukan tata usaha bersifat pelayanan terhadap pekerjaan pokok di dalam organisasi. tetapi tata usaha tidak boleh diremehkan.

Tata Usaha perlu mendapatkan perhatian yang sewajarnya, karena tata usaha Juga ikut menentukan berhasil atau tidaknya tujuan organisasi tercapai secara efisien. Kiranya cukup beralasan bila dilanjutkan kepada setiap pimpinan organisasi dan para pelaksana tata usaha untuk tidak meremehkan tata uaha akan tetapi sebaliknya, perlu mendapat perhatian yang sungguhsungguh karena memang tata usaha mempunyai peranan yang sangat penting.

Adapun kedudukan dan peranan tata usaha dalam organisasi adalah sebagai berikut :

1. Tata Usaha melayani pekerjaanpekerjaan operatif umuk mencapai tujuan organisasi.

2. Tata Usaha menyediakan keterangan-keterangan bagi pucuk pimpinan organisasi untuk membuat keputusan atau melakukan tindakan yang tepat.

3. Tata Usaha membantu kelancaran perkembangan organisasi sebagai suatu keseluruhan, karena tata usaha berkenaan dengan dokumendokumen dan dokumen-dokumen sebagai sumber ingatan.
Bilamana tata usaha tidak ditata dengan sebaik-baiknya, sudah tentu pekerjaan akan menjadi kacau, keputusan yang dibuat pimpinan terlambat, sulitnya organisasi yang bersangkutan untuk berkembang, menghambat kelancaran tugas para pegawai dan sudah tentu pula bahwa tujuan organisasi tidak akan tercapai secara efektif dan efisien.

Bertolak dari pengertian tata usaha yang telah penulis paparkan di atas, maka dapat penulis uraikan fungsi tata usaha dalam organisasi sebagai berikut :

1. Menghimpun yaitu kegiatan yang mengumpulkan keterangan yang sebelumnya tidak ada atau terserok kemana-mana supaya dapat berguna.

2. Mencatat yaitu kegiatan dengan mencatat segala aktivitas mengenai suatu keterangan, misalnya memberi nomor surat, menggandakan surat dan lain sebagainya.

3. Mengolah yaitu kegiatan yang mengusahakan keterangan yang berguna, mengolah yang berguna agar lebih menjadi berguna. Mengolah dan bermanfaat bagi organisasi.

4. Menggandakan yaitu kegiatan yang memperbanyak keteranganketerangan dengan jalan diketik, distensil atau dicetak misalnya mencetak peraturan-peraturan bagi organisasi dan sebegainya.

5. Mengirim yaitu kegiatan atau menyampaikan suatu keterangan dari satu pihak ke pihak lainnya misalnya menyampaikan melalui radio, atau mengirim berita dengan surat biasa. 
6. Menghimpun yaitu kegiatan menaruh suatu keterangan pada tempat tertentu dan aman misalnya menyimpan dokumen-dokumen ke dalam arsip atau kedalam almari untuk bahan kearsipan yang dibutuhkan sewaktu-waktu.

Hal tersebut di atas memberikan arti bahwa kedudukan/peranan dan fungsi tata usaha dalam organisasi sangat dominan dalam mencapai tujuan organisasi yang telah digariskan.

\section{E. Hubungan Tata Usaha dengan Kelancaran Tugas}

Hubungan antara tata usaha dengan kelancaran tugas pegawai sangat erat sekali, halmana sebelumnya kelancaran tugas pegawai menentukan arah kefektifan pegawai dalam menjalankan tugasnya sehingga dapat mencapai tujuan yang telah ditentukan sebelumnya, tentunya dalam rangka menciptakan kelancaran tugas pegawai di dalam suatu organisasi atau instansi melalui peranan tata usaha, sebaga berikut :

1. Tata Usaha melayani pelaksanaan pekerjaan-pekerjaan operatif untuk mencapai tujuan organisasi.

2. Tata Usaha menyediakan keterangan-keterangan bagi pucuk pimpinan organisasi untuk membuat keputusan atau melakukan tindakan yang tepat.

3. Tata Usaha membantu perkembangan organisasi sebagai suatu keseluruhan, karena tata usaha berkenaan dengan dokumendokumen dan dokumen-dokumen sebagai sumber ingatan.

Dengan adanya unsur tersebut di atas, tentunya akan sangat memudahkan pegawai dalam menjalankan tugasnya. Hal ini sejalan dengan pengertian kelancaran tugas itu sendiri yaitu serangkaian tindakan yang dijalankan seseorang/kelompok dalam suatu lingkungan tertentu dengan menyingkirkan hambatan-hambatan dan memberi kesempatan-kesempatan terhadap pelaksanaan tugas tersebut dalam rangka mencapai tujuan tertentu.

Dengan kata lain bahwa tata usaha berperan dalam menyajikan informasi/data yang diperlukan agar produk yang dihasilkan rasional dan efektif.

\section{METODOLOGI PENELITIAN}

\section{A. Metode Penelitian Yang Digunakan}

Metodologi penelitian yang digunakan adalah metode penelitian deskriptif, dimaksudkan untuk menjajaki suatu fenomena atau gejala dan kenyataan, berkenaan dengan masalah dan unit yang diteliti, yaitu peran pengendalian tata usaha untuk menunjang kelancaran pelaksanaan tugas.

\section{B. Operasional Variabel}

Yang dimaksud variable penelitian yaitu dimensi-dimensi yang dapat diukur dan ditelitihal mana dimensi tersebut merupakan jabaran yang terkandung di Dalam judul.

a. Variable Bebas (X)

Variable bebas adalah variable yang mempengaruhi, dalam hal ini adalah pengendalian tata usaha.

Variable ini akan diukur dengan :

- Prosedur yang tepat

- Proses yang cepat

- Kerjasama

- Sesuai aturan

b. Variabel Terikat (Y)

Variabel terikat adalah variabel yang dipengaruhi, dalam hal ini adalah kelancaran tugas.

Variabel ini akan diukur dengan : 
- Penyelesaian tugas cepat

- Penyelesaian tugas tepat

- Penyelesaian tugas sesuai aturan

- Penyelesaian tugas bertanggungjawab

\section{Populasi dan Sampel}

1. Populasi

Populasi adalah keseluruhan dari subyek penelitian (Suharsimi Arikunto, 2003 : 102). Berdasarkan pendapat tersebut, maka yang akan menjadi populasi dalam penelitian ini adalah seluruh staff tata usaha dan guru yang ada pada SDN 1 Way Gubak Kecamatan Panjang Kota Bandar Lampung yang berjumlah 12 orang.

\section{Sampel}

Sampel adalah bagian dari populasi yang diteliti (Suharsimi Arikunto, 2003 : 107). Selanjutnya menurut Suharsimi Arikunto, apabila subyek lebih dari 100, maka sampel dapat diambil $10-15 \%$ atau $20-25 \%$ atau lebih dan apabila subyek penelitian kurang dari 100, lebih baik diambil semuasehingga penelitian merupakan penelitian populasi. Dalam hal ini sampel yang dijadikan responden sebanyak 12 orang.

\section{Sumber Data}

Sumber data primer yaitu data pokok/utama yang diperoleh langsung di lapangan terhadap obyek yang diteliti, berdasarkan hasil observasi, wawancara dan kuisioner.

Sumber data sekunder yaitu data pelengkap/penunjang yang diperoleh dari hasil meneliti dokumen dan kepustakaan yang ada kaitannya dengan obyek yang diteliti.

\section{E. Teknik Pengumpulan Data}

Dalam pengumpulan data, peneliti menggunakan teknik-teknik sebagai berikut :

1. Penelitian Kepustakaan (Library Research)

Yaitu penelitian yang dilakukan dengan mengumpulkan data atau pendapat para ahli atau ilmuan yang berhubungan dengan obyek yang diteliti, dari buku literatur atau lainnya yang dapat mendukung peneliti dalam membahas masalah yang dihadapi.

2. Penelitian Lapangan (Field Research)

Yaitu penelitian yang dilakukan langsung dilapangan dengan cara :

a. Observasi

Teknik ini dilakukan melalui pengamatan yang secara langsung terhadap obyek yang diteliti.

b. Wawancara

Teknik ini dilakukan dengan cara mengajukan pertanyaan secara lisan kepada beberapa responden berkaitan dengan obyek yang diteliti.

Teknik ini dimaksudkan untuk mengetahui dan memperjelas serta melengkapi jawaban responden melalui kuisioner.

c. Dokumentasi

Teknik ini dilakukan dengan cara melihat dokumendokumen, atau risalah-risalah yang berhubungan dengan obyek yang diteliti.

d. Kuisioner

Teknik ini digunakan untuk memperoleh data primer dengan mengajukan daftar pertanyaan yang berkaitan dengan pengendalian tata usaha 
dan kelancaran pelaksansan tugas.

\section{F. Metode Analisis Data}

Data yang telah terkumpul melalui kegiatan pengumpulan data, diproses melalui pengolahan dan penyajian data. Data-data tersebut diseleksi, Dievaluasi untuk kemudian dianalisis melalui pendekatan Normatif, yaitupendekatan yang dilakukan dengan melihat dan meneliti dokumentasi serta mengkaji berbagai peraturan hukum yang berkaitan dengan permasalahan. Empiris, yaitu pendekatan yang dilakukan dengan cara mempelajari kenyataan-kenyataan yang ada di lapangan, khususnya yang ada kaitan dengan permasalahan yang diteliti. Analisis data akan dilakukan :

1. Analisis Korelasi antara Variabel X (peran pengendalian tata usaha) dengan variable $\mathrm{Y}$ (kelancaran tugas). Analisis korelasi ini mengunakan rumus statistik corelation pearson product moment yaitu sebagai berikut :

$r_{x y}=\frac{\text { n. }\left(\sum x y\right)-\left(\sum x\right)\left(\sum Y\right)}{\sqrt{\left(n \cdot \sum x^{2}-\left(\sum X\right)^{2}\right)\left(n \cdot \sum Y^{2}-\left(\sum Y\right)^{2}\right)}}$

Tujuan digunakan analitis korelasi dengan rumus tersebut di atas, adalah untuk mengetahui ke-eratan hubungan kedua variabel ( $\mathrm{X}$ dan Y).

Keterangan Rumus :

Rxy = Koefisien Korelasi X dan Y

$\mathrm{n}=$ Jumlah Sampel/Responden

$\sum \mathrm{X}=$ Jumlah Skor Variabel $\mathrm{X}$

$\sum Y=$ Jumlah Skor Variabel $\mathrm{Y}$

$\sum X^{2}=$ Jumlah Skor Variabel $\mathrm{X}$ Kuadrat $\sum Y^{2}=$ Jumlah Skor Variabel $\mathrm{Y}$ Kuadrat

2. Uji Hipotesis, menggunakan uji t sebagai berikut :

$$
t=\frac{\sqrt{n-2}}{\sqrt{l-r^{2}}}
$$

(Suharsimi Arikunto, 2003 : 114)

Ketentuan Hipotesis :

$\mathrm{H}_{\mathrm{o}}$ : ditolak jika $\mathrm{t}_{\text {hilang }}$ lebih besar atau sama dengan $\mathrm{t}_{\text {tabel }}\left(\mathrm{H}_{1}\right.$ diterima $)$

$\mathrm{H}_{\mathrm{o}}$ : diterima jika $\mathrm{t}_{\text {hilang }}$ lebih kecil atau sama dengan $\mathrm{t}_{\text {tabel }}\left(\mathrm{h}_{1}\right.$ ditolak)

Digunakan uji t dalam uji hipotesis penulis, karena variabel penelitian hanya 2 (dua) variabel, disamping itu populasi dan sampel penelitian kurang dari 100.

\section{HASIL PENELITIAN DAN PEMBAHASAN}

\section{A. Gambaran Umum Obyek Penelitian}

Pada tahun 1980, masyarakat kampung Way Gubak yang beranda di wilayah Kecamatan Panjang sangat mendambakan gedung sekolah. Hal ini disebabkan anak-anak yang akan masuk sekolah dasar harus menempuh perjalanan lebih dari 2 (dua) kilometer dengan berjalan kaki. Saat itu gedung sekolah ada di wilayah Teluk Betung Selatan.

Pada tahun 1982, pemerintah mewujudkan harapan masyarakat kampung Way Gubak dengan membangunan satu unit Sekolah Dasar (SD) Inpres. Dengan memanfaatkan tanah/lahan yang miring dan bebatuan, masyarakat bergotong royong mendirikan sekolah tersebut.

Pada tahun 1982 resmi berdiri dengan 4 (empat) ruang kelas yang dapat menampung 120 orang siswa dalam proses belajar mengajar. Proses belajar 
mengajar dapat berjalan dengan baik dan lancer, pada saat itu Kepala Sekolah dipimpin oleh Bapak Ismail, dengan nama sekolah SDN 1 Way Gubak.

B. Tata Kerja Pegawai Tata Usaha SDN 1 Way Gubak Kecamatan Panjang Kota Kota Bandar Lampung.

1. Bagian Tata Usaha Begian Tata Usaha mempunyai tugas menyelenggarakan Urusan Perencanaan, Kepegawaian, Keuangan dan Umum.

Untuk menyelenggarakan tugas tersebut, bagian tata usaha mempunyai fungsi :

a. Melaksanakan kegiatan ketatausahaan, kepegawaian, keuangan, perlengkapan dan kerumahtanggaan Sekolah.

b. Memberikan pelayanan Administrasi bagi seluruh guru SDN 1 Way Gubak Kecamatan Panjang Kota Bandar Lampung.

c. Memberikan pertimbangan kepada Kepala Sekolah mengenai hal-hal yang ada hubungannya dengan masalah yang timbul akibat pelaksanaan tugas guru.

d. Mengusahakan terciptanya tertib administrasi, tertib organisasi dan tertib hukum bagi seluruh pegawai di Lingkungan SDN 1 Way Gubak.

e. Mengumpulkan dan mengelola bahan/informasi di bidang administrasi serta mengajukan pemecahan masalah dan pertimbangannya kepada Kepala Sekolah. f. Melaksanakan tugas-tugas lain yang diberikan oleh Kepala Sekolah.

Tata Kerja Bagian Tata Usaha terdiri dari :

a. Urusan Surat Menyurat Urusan Surat Menyurat mempunyai tugas :

- Mencatat surat masuk dan keluar dalam buku Agenda dan buku Expedisi.

- Menerima dan menyampaikan surat-surat yang masuk atau suratsurat yang keluar.

- Mengatur, memelihara, menyimpan arsip dan dokumen sekolah.

- Melaksanakan pengetikkan dan pengadaan surat menyurat. Mempersiapkan dan menyusun pedoman serta petunjuk TataLaksana Administrasi Umum.

- Mempersiapkan rancangan Peraturan/Keputusan yang berkaitan dengan tugas Kepala Sekolah dan Guru.

- Melaksanakan tugas-tugas lain yang diberikan oleh Kepala Sekolah.

Dalam melaksanakan tugastugasnya, Kepala Tata Usaha menerapkan prinsip koordinasi, integrasi, dalam lingkungan sekolah untuk kesatuan gerak yang Serasi sesuai dengan bidang tugasnya. Kepala Tata Usaha melaksanakan tugasnya berdasarkan kebijaksanaan yang ditetapkan oleh Walikota dan Kepala Sekolah. 


\section{Pelaksanaan Fungsi dan Peranan Tata Usaha SDN 1 Way Gabak Kecamatan Panjang Kota Bandar Lampung}

Bertitik tolak kepada pada kebijakan yang ada tentang struktur Organisasi dan Tata Kerja Sekolah SDN 1 Way Gubak Kecamatan Panjang Kota Bandar Lampung, menempatkan Kepada Tata Usaha dalam kedudukan ganda, yaitu sebagai staf Kepala Sekolahdan sebagai pimpinan tata usaha yang ada dalam lingkup sekolah, maka berdasarkan kedudukan tersbut Kepala Tata Usaha dituntut dapat melaksanakan tugas, fungsi dan peranannya dengan sebaik-baiknya sesuai dengan batas-batas kewenangan yang dilimpahkan kepadanya.

Untuk menguraikan fungsi dan peranan Kepala Tata Usaha kiranya perlu untuk diuraikan pula tugasnya, oleh karena itu dibawah Ini akan penulis uraikan sebagai berikut:

1. Melaksanakan semua tugas yang berkenaan dengan ketata usahaan/administrasi sekolah.

2. Melaksanakan tugas pengelolaan keuangan sekolah

3. Melaksanakan tugas menyangkut pendidikan dan kesejahteraan guru

4. Mengurus sarana/prasarana sekolah dan perawatannya

5. Menyelenggarakan hubungan antara guru, komite, siswa wali murid

6. Menyelenggarakan keamanan dan kenyaman dalam lingkungan sekolah

7. Mengurus kegiatan keolahragaan

8. Menyusun dan menyimpan laporan

9. Melaksanakan urusan rumah tangga sekolah termasuk organisasi intra sekolah
Fungsi Tata Usaha antara Iain Mengkoordinasikan dan mengintegrasikan seluruh kegiatan dibidang administratif di dalam lingkungan sekolah sehingga diharapkan akan tercapai keterpaduan dalam rangka melaksanakan tugastugas guru sesuai dengan tujuan pembelajaran.

Peranan Kepala Tata Usaha dalam ketentuan organisasi sekolah mempunyai kewajiban dan tanggung jawab dalam melaksanakan tugasnya, sebegai tata usaha harus dapet melaksanakan tugas dan kewajibannya didasarkan pada wewenang yang melekat pada jabatan tersebut, dalam hal ini yang maksudkan adalah hak untuk bertindak, memberi perintah atau untuk menimbulkan tindakan-tindakan bagi orang lain.

Kepala Tata Usaha dapat berperan sebagai pemegang wewenang pada bagiannya, yang berfungsi sebagai staf dan Kepala Tata Usaha sekolah, peran yang dimaksud adalah sebagai berikut :

1. Kepala Tata Usaha berdasarkan wewenang yang ada padanya harus dapat menggerakkan semua personil yang berada pada bagiannya dalam mencapai tujuan sesuai dengan garis yang telah ditetapkan.

2. Kepala Tata Usaha sebegai motivator, umumnya dapat semua personil yang berada pada bagiannya untuk dapat melaksanakan tugas dengan penuh kesadaran dan rasa tanggung jawab sehingga dapat tercipta suasana kerja yang dinamis.

3. Kepala Tata Usaha di setiap kegiatan dalammenggerakkan 
personil maupun material harus melaksanakan fungsi kontrol secara kontinue Sehingga setiap tingkat kegiatan dapat dievaluasi.

Sebagai staf Kepala Tata Usaha pada sekolah SDN 1 Way Gubak Kecamatan Panjang Kota Bandar Lampung melaksanakan tugas sebegai berikut :

1. Memberikan saran-saran atau penilaian-penilaian teknis ataupun administratif kepada guru sebelum Kepala Sekolah membuat atau merumuskan kebijaksanaan yang dipandang perlu dalam tujuan kegiatan belajar mengajar.

2. Dalam keperluan itu Kepala Tata Usaha memberikan informasiinformasi yang diperlukan oleh Kepala Sekolah yang mungkin dapat menghambat pelaksanaan tugas teknis operasional maupun tugas administratif yang mungkin menyimpang dari ketentuan yang berlaku.

3. Memberikan laporan kepada Kepala Sekotah dalam rangka pelaksanaan tugas, baik tugas teknis operasional maupun tugastugas administratif khusunya di dalam bidang administrasi keuangan sekolah.

\section{Peran Pengendalian Tata Usaha} dalam Menunjang Kelancaran Tugas SDN 1 Way Gubak Kecamatan Panjang Kota Bandar Lampung terhadap Hasil yang Dicapai

Untuk mengetahui lebih peran pengendalian tata usaha dalam menunjang kelancaran tugas SDN 1 Way Gubak Kecamatan Panjang Kota Bandar Lampung, di bawah ini akan penulis sajikan tabel hasil jawaban kuisioner yang penulis sebarkan kepada 12 responden penelitian, di mana Setiap jawaban responden diberi skor sebagai berikut :

- Apabila responden menjawab dalam kategori a maka diberi skor 3

- Apabila responden menjawab dalam kategori b maka diberi skor 2

- Apabila responden menjawab dalam kategori c maka diberi skor 1

\section{Hasil Jawaban Responden Mengenai Variabel X}

(Pengendalian Tata Usaha)

Tabet 1. Jawaban responden mengenai prosedur-prosedur yang dijalankan dalam ketatausahaan.

\begin{tabular}{|ll|c|c|}
\hline Jawaban & Jumlah & Prosentase \\
\hline a. Tepat & 10 & $83, \%$ \\
b. Kurang tepat & 2 & $17 \%$ \\
c. Tidak tepat & - & - \\
\hline \multicolumn{2}{|c|}{ Jumlah } & 12 & $100 \%$ \\
\hline \multicolumn{3}{|c|}{ Sumber : Data diolah 2012 }
\end{tabular}

Dari Tabel 1 di atas, sebanyak 10 responden $(83 \%)$ menjawab dalam kategori (a) dalam arti bahwa prosedurprosedur yang dijalankan dalam ketatausahaan sekolah adalah tepat, dan 2 responden (17\%) menjawab dalam kategori (b) dalam arti bahwa prosedurprosedur yang dijalankan dalam ketatausahaan kurang tepat, dan tidak ada satupun responden yang menjawab dalam kategori (c) tidak tepat. Dengan demikian dapat diartikan bahwa prosedur-prosodur yang dijalankan dalam ketatausahaan SDN 1Way Gubak Kecamatan Panjang Kota Bandar Lampung dalam kategori tepat. 
Tabel 2. Jawaban responden mengenai proses tata usaha yang ada.

\begin{tabular}{|c|c|c|}
\hline Jawaban & Jumlah & Prosentase \\
\hline a. Tepat & 10 & $83, \%$ \\
\hline b. Kurang tepat & 2 & $17 \%$ \\
\hline c. Tidak tepat & - & - \\
\hline Jumlah & 12 & $100 \%$ \\
\hline
\end{tabular}

Sumber : Data diolah, 2012

Dari tabel 2 di atas, sebanyak 10 responden $(83 \%)$ menjawab dalam kstegori jawaban (a) dalam arti proses tata usaha yang dijalankan adalah cepat, dan sebanyak 2 responden (17\%) menjawab dalam kategori jawaban (b) dalam arti proses tata usaha yang dijalankan kurang cepat, dan tidak ada satu respondenpun yang menjawab dalam kategori jawaban (c) tidak cepat.

Dengan demikian dapat di ambil kesimpulan bahwa proses tata usaha yang dijalankan pada SDN I Way Gubak Kecamatan Panjang Bandar Lampung dalam kategori cepat.

Tabel 3. Jawaban responden mengenai kerjasama dalam tugas.

\begin{tabular}{|c|c|c|}
\hline Jawaban & Jumlah & Prosentase \\
\hline a. Tepat & 8 & $67 \%$ \\
\hline b. Kurang & 4 & $33 \%$ \\
\hline tepat & $\begin{array}{lll}- & - \\
-1\end{array}$ & - \\
\hline c. Tidak tepat & & \\
\hline Jumlah & 12 & $100 \%$ \\
\hline
\end{tabular}

Sumber : Data diolah 2012

Dari tabel 3 di atas, terdapat 8 (67\%) responden yang menjawab dalam kategori (a), dalam arti kerjasama pelaksanaan tugas ketatausahaan pada SDN 1 Way Gubak Kecamatan Panjang Kota Bandar Lampung adalah baik, sebanyak 4 responden (33\%) menjawab dalam kategori (b), dalam arti kerjasama pelaksanaan tugas ketatausahaan pada SDN 1 Way GubakKecamatan Panjang Kota Bandar Lampung kurang baik, dan tidak ada responden yangmenjawab dalam kategori (c) dalam arti kerjasama SDN 1 Way Gubak Kecamatan Panjang Kota Bandar Lampung tidak baik. Dengan demikian dapat disimpulkan bahwa kerjasama dalam melaksanakan tugas pada SDN 1 Way Gubak Kecamatan Panjang Kota Bandar Lampung adalah baik.

Tabel 4. Jawaban responden mengenai sesuai dengan aturan.

\begin{tabular}{|c|c|c|}
\hline Jawaban & Jumlah & Prosentase \\
\hline a. Tepat & 8 & $67 \%$ \\
\hline b. Kurang tepat & 4 & $33 \%$ \\
\hline c. Tidak tepat & - & - \\
\hline Jumlah & 12 & $100 \%$ \\
\hline
\end{tabular}

Sumber : Data diolah 2012

Dari tabel 4 di atas, dapat diketahui bahwa sejumlah 8 (67\%) responden menjawab dalam kategori (a) dalam arti pelaksanaan tugas ketatausahaan pada SDN 1 Way Gubak Kecamatan Panjang Kota Bandar Lampung telah sesuai dengan aturan, sebanyak 4 (33\%) responden menjawab dalam kategori (b) dalam arti pelaksanaan tugas ketsausahsan pada SDN I Way Gubak Kecamatan Panjang Kota Bandar Lampung kurang sesuai dengan aturan, dan tidak ada responden yang menjawab pelaksanaan tugas ketatausahaan pada SDN 1 Way Gubak Kecamatan Panjang Kota Bandar Lampung tidak sesuai aturan.

Dengan demikian berdasarkan tabel 4 tersebut dapat disimpulkan bahwa pelaksanaan tugas ketatausahaan pada SDN 1 Way Gubak Kecamatan Panjang 
Kota Bandar Lampung telah sesuai dengan aturan.

Untuk mengetahui lebih jelas mengenai kegiatan ketatausahaan yang telah dilakukan oleh SDN 1 Way Gubak
Kecamatan Panjang Kota Bandar Lampung, berikut penulis sajikan tabel distribusi kumulatif hasil jawaban responden mengenai variabel $\mathrm{X}$ (peran pengendalian tatausaha):

Tabel 5 : Distribusi kumulatif jawaban responden tentang variabel X (Peran Pengendalian Tata Usaha)

\begin{tabular}{|c|c|c|c|c|}
\hline \multirow{2}{*}{$\begin{array}{c}\text { INDIKATOR } \\
\text { PERANAN TATA USAHA }\end{array}$} & \multicolumn{3}{|c|}{ KATEGORI } & \multirow[t]{2}{*}{ TOTAL } \\
\hline & BAIK & KURANG & TIDAK & \\
\hline 1. Prosedur & $83 \%$ & $17 \%$ & - & $100 \%$ \\
\hline 2. Proses & $83 \%$ & $17 \%$ & - & $100 \%$ \\
\hline 3. Kerjasama & $67 \%$ & $33 \%$ & - & $100 \%$ \\
\hline 4. Sesuai aturan & $67 \%$ & $33 \%$ & - & $100 \%$ \\
\hline Jumlah & $300 \%$ & $100 \%$ & - & $400 \%$ \\
\hline Rata-rata & $75 \%$ & $25 \%$ & - & $100 \%$ \\
\hline
\end{tabular}

Sumber : Data diolah, 2012

Dari tabel distribusi kumulatif tersebut di atas, menunjukkan bahwa tata usaha yang dilakukan okeh SDN 1 Way Gubak Kecamatan Panjang Kota Bandar Lampung, yang diukur dengan Indikator prosedur, proses, kerjasama, dan sesuai aturan, dalam kategori baik berjumlah $300 \%$ dengan jumlah rata-tata $75 \%$, sedangkan dalam kategori kurang baik berjumlah $100 \%$ dengan Jumlah rata-rata $25 \%$ dan dalam kategori tidak baik tidak ada.

Dengan demikian dapat disimpulkan bahwa tata usaha yang dilakukan SDN 1 Way Gubak Kecamatan Panjang Kota Bandar Lampung dalam kategori baik, hal ini berarti peran pengendalian tata usaha telah dilakukan dengan baik.

\section{Hasil Jawaban Responden Mengenai Variabel Y}

(Kelancaran Tugas Pegawai)
Tabel 6. Jawaban responden mengenai waktu penyelesaian tugas.

\begin{tabular}{|c|c|c|}
\hline Jawaban & Jumlah & Prosentase \\
\hline a. Cepat & 10 & $83 \%$ \\
\hline $\begin{array}{l}\text { b. Kurang } \\
\text { cepat } \\
\text { c. Tidak cepat }\end{array}$ & $\begin{array}{l}2 \\
-\end{array}$ & $17 \%$ \\
\hline Jumlah & 12 & $100 \%$ \\
\hline
\end{tabular}

Dari hasil tabel 6 di atas, terlihat 10 responden $(83 \%)$ yang menjawab dalam kategori (a) dalam arti bahwa penyelesaian tugas telah dilaksanakan dengan cepat, dan sebanyak 2 responden (17\%) menjawab dalam kategori (b) dalam arti penyelesaian tugas kurang Cepat, sedangkan yang menjawab dalam kategori (c) tidak ada. Dengan demikian berdasarkan tabel 6 tersebut, dapat disimpulkan bahwa penyelesaian tugas yang dilakukan oleh tata usaha SDN 1 Way Gubak Kecamatan Panjang Kota Bandar Lampung telah dilakukan dengan cepat. 
Tabel 7. Jawaban responden mengenai ketepatan menyelesaikan tugas.

\begin{tabular}{|c|c|c|}
\hline Jawaban & Jumlah & Prosentase \\
\hline a. Tinggi & 8 & $67 \%$ \\
\hline b. Kurang & 4 & $33 \%$ \\
\hline Tinggi & - & - \\
\hline Jumlah & 12 & $100 \%$ \\
\hline
\end{tabular}

Sumber : Data diolah, 2012

Dengan berdasarkan pada tabel 7 di atas, maka terlihat bahwa terdapat $8(67 \%)$ responden menjawab dalam kategori (a) dalam arti bahwa penyelesaian tugas oleh tata usaha SDN I Way Gubak Kecamatan Panjang Kota Bandar Lampung telah dilakukan dengan tepat, dan sebanyak 4 (33\%) responden menjawab dalam kategori (b) dalam arti penyelesaian tugas oleh tata usaha SDN I Way Gubak Kecamatan Panjang Kota Bandar Lampung kurang dilakukan dengan tepat, dan tidak ada responden yang menjawab dalam kategori (c) dalam arti penyelesaian tugas oleh tata usaha SDN 1Way Gubak Kecamatan Panjang Kota Bandar Lampung telah dilakukan tidak tepat. Dengan demikian bila melihat hasil tabel 7 di atas, maka dapat disimpulkan bahwa penyelesaian tugas oleh tata usaha SDN 1 Way Gubak Kecamatan Panjang Kota Bandar Lampung telah dilakukan dengan tepat.

Tabel 8. Jawaban responden mengenai kesesuaian dengan aturan.

\begin{tabular}{|c|c|c|}
\hline Jawaban & Jumlah & Prosentase \\
\hline a. $\mathrm{Ya}$ & 8 & $67 \%$ \\
\hline b. Kurang & 4 & $33 \%$ \\
\hline c. Tidak & - & - \\
\hline Jumlah & 12 & $100 \%$ \\
\hline
\end{tabular}

Sumber : Data diolah, 2012

Dari tabel 8 di atas, dapat diketahui bahwa sejumlah 8 (67\%) responden menjawab dalam kategori (a) dalam arti pelaksanaan tugas ketatausahaan pada SDN 1Way
Gubak Kecamatan Panjang Kota Bandar Lampung telah sesuai dengan utusan, sebanyak 4 (33\%) responden menjawab dalam kategari (b) dalam arti pelaksanaan tugas ketatausahaan pada SDN 1 Way Gubak Kecamatan Panjang Kota Bandar Lampung kurang sesuai dengan aturan, dan tidak ada responden yang menjawab pelaksanaan tugas ketatausahaan pada SDN 1 Way Gubak Kecamatan Panjang Kota Bandar Lampung tidak sesuai aturan.

Dengan demikian berdasarkan table 8 tersebut dapat disimpulkan bahwa pelaksanaan tugas ketatausahaan pada SDN 1 Way Gubak Kecamatan Panjang Kota Bandar Lampung telah sesuai dengan aturan.

Tabel 9. Jawaban responden mengenai tanggungjawab.

\begin{tabular}{|cl|c|c|}
\hline Jawaban & $\begin{array}{c}\text { Juml } \\
\text { ah }\end{array}$ & $\begin{array}{c}\text { Prosent } \\
\text { ase }\end{array}$ \\
\hline a. & Bertanggungjaw & 9 & $75 \%$ \\
& ab & 3 & $25 \%$ \\
b. & Kurang & - & - \\
& bertanggungjaw & \\
& ab & \\
c. & Tidak & 12 & $100 \%$ \\
\hline \multicolumn{2}{|c|}{ Jumlah } & \\
\hline \multicolumn{2}{|c|}{ Sumber : Data diolah, 2012 }
\end{tabular}

Dengan berdasarkan pada tabel 9 tersebut di atas, terlihat bahwa terdapat 9 responden (75\%) menjawab dalam kategori (a) dalam arti pelaksanaan tugas ketatausahaan SDN 1 Way Gubak Kecamatan Panjang Kota Bandar Lampung telah dilakukan dengan tanggungjawab, dan sebanyak 3 (25\%) responden menjawab dalam kategori (b) dalam arti pelaksanaan tugas ketatausahaan SDN 1 Way Gubak Kecamatan Panjang KotaBandar Lampung kurang dilakukan dengan tanggungjawab, dan tidak responden yang menjawab dalam kategori (c). 
Dengan demikian berdasarkan pada hasil tabel 9 di atas, maka dapat disimpulkan bahwa pelaksanaan tugas ketatausahaan pada SDN 1 Way Gubak Kecamatan Panjang Kota Bandar Lampung dilakukan dengan tanggungjawab.

Untuk mengetahui lebih jelas mengenai kelancaran pelaksanaan tugas ketatausahaan SDN 1 Way Gubak Kecamatan Panjang Kota Bandar Lampung, berikut penulis sajikan tabel distribusi kumulatif hasil jawaban responden mengenai variabel $\mathrm{Y}$ (kelancaran tugas pegawai), sebagai berikut :

Tabel 10. Distribusi kumulatif jawaban responden tentang variabel $\mathrm{Y}$

(Kelancaran Tugas)

\begin{tabular}{|c|c|c|c|c|}
\hline INDIKATOR KELANCARAN TUGAS & \multicolumn{3}{|c|}{ KATEGORI } & \multirow{2}{*}{ TOTAL } \\
\cline { 2 - 4 } PEGAWAI & BAIK & KURANG & TIDAK & \\
\hline 1. Penyelesaian Tugas Cepat & $83 \%$ & $17 \%$ & - & $100 \%$ \\
2. Penyelesaian Tugas Tepaat & $67 \%$ & $33 \%$ & - & $100 \%$ \\
3. Sesuai Aturan & $67 \%$ & $33 \%$ & - & $100 \%$ \\
4. Bertanggungjawab & $75 \%$ & $25 \%$ & - & $100 \%$ \\
\hline Jumlah & $292 \%$ & $108 \%$ & - & $400 \%$ \\
\hline Rata-rata & $73 \%$ & $27 \%$ & - & $100 \%$ \\
\hline
\end{tabular}

Sumber : Data diolah, 2012

Dari tabel distribusi kumulatif tersebut di atas, menunjukkan bahwa kelancaran tugas pada SDN 1 Way Gubak Kecamatan Panjang Kota Bandar Lampung, yang diukur dengan indikator penyelesaian tugas cepat, penyelesaian tugas tepat, sesuai aturan dan bertanggungjawab dalam kategori baik berjumlah $292 \%$ dengan jumlah rata-rata $27 \%$, dan tidak ada responden yang menjawab tidak bertanggungjawab.

Dengan demikian dapat disimpulkan bahwa kelancaran pelaksanaan tugas pada SDN I Way Gubak Kecamatan Panjang Kota Bandar Lampung adalah dalam kategori baik.

1. Analisis Korelasi
Hasil penyebaran kuisioner yang berjumlah 8 pertanyaan mengenai variabel $\mathrm{X}$ (pengendalian tata usaha) dan variabel Y (Kelancaran Tugas), diperoleh skor data hasil jawaban responden, Skor hasil jawaban responden tersebut akan penulis sajikan kedalam bentuk tabel guna untuk memudahkan penulis mengetahui nilai dari masing-masing variabel agar tidak terjadi penyimpangan di dalam penganalisaan data secara kuantitatif. Penganalisaan data secara kuantitatif ini akan penulis lakukan dengan cara mendistribusikan hasil skor jawaban responden masing-masing variabel tersebut ke dalam bentuk tabel sebagai berikut : 
Tabel 11. Skor Hasil Jawaban Responden Mengenai Variabel X (Pengendalian Tata Usaha)

\begin{tabular}{|c|c|c|c|c|c|c|c|c|c|c|}
\hline \multirow{4}{*}{ RESPONDEN } & \multicolumn{10}{|c|}{ JUMLAH PERTANYAAN } \\
\hline & \multicolumn{10}{|c|}{ SKOR } \\
\hline & \multicolumn{5}{|c|}{ VARIABEL $\mathrm{X}$} & \multicolumn{5}{|c|}{ VARIABEL Y } \\
\hline & 1 & 2 & 3 & 4 & TOTAL $\mathrm{X}$ & 5 & 6 & 7 & 8 & TOTAL Y \\
\hline 1 & 3 & 3 & 2 & 3 & 11 & 3 & 3 & 3 & 3 & 12 \\
\hline 2 & 3 & 3 & 3 & 3 & 12 & 3 & 3 & 3 & 3 & 12 \\
\hline 3 & 3 & 3 & 3 & 3 & 12 & 3 & 3 & 3 & 3 & 12 \\
\hline 4 & 3 & 3 & 3 & 3 & 12 & 3 & 3 & 2 & & 11 \\
\hline 5 & 3 & 2 & 3 & 2 & 10 & 3 & 2 & 2 & 3 & 10 \\
\hline 6 & 3 & 2 & 3 & 3 & 11 & 3 & 3 & 3 & 3 & 12 \\
\hline 7 & 3 & 3 & 3 & 2 & 11 & 3 & 2 & 3 & 3 & 11 \\
\hline 8 & 3 & 3 & 3 & 3 & 12 & 3 & 2 & 3 & 2 & 10 \\
\hline 9 & 3 & 3 & 3 & 2 & 11 & 3 & 2 & 3 & 3 & 11 \\
\hline 10 & 2 & 3 & 2 & 3 & 10 & 3 & 3 & 3 & 3 & 12 \\
\hline 11 & 2 & 3 & 2 & 2 & 9 & 3 & 3 & 3 & 3 & 12 \\
\hline 12 & 3 & 3 & 2 & 3 & 11 & 3 & 3 & 3 & 3 & 12 \\
\hline JUMLAH & \multicolumn{4}{|c|}{ JUMLAH } & 132 & \multicolumn{4}{|c|}{ JUMLAH } & 137 \\
\hline
\end{tabular}

Sumber : Data diolah, 2012

Kemudian langkah selanjutnya adalah membuat tabel tugas, yaitu sebagai berikut :

Tabel 12. Tabel Kerja Product Moment.

\begin{tabular}{|c|c|c|c|c|c|}
\hline NO & $\mathrm{X}$ & $\mathrm{Y}$ & $\mathrm{X}^{2}$ & $\mathrm{Y}^{2}$ & $\mathrm{XY}$ \\
\hline 1 & 11 & 12 & 121 & 144 & 132 \\
2 & 12 & 12 & 144 & 144 & 144 \\
3 & 12 & 12 & 144 & 144 & 144 \\
4 & 12 & 11 & 144 & 121 & 132 \\
5 & 10 & 10 & 100 & 100 & 100 \\
6 & 11 & 12 & 121 & 144 & 132 \\
7 & 11 & 11 & 121 & 121 & 121 \\
8 & 12 & 10 & 144 & 100 & 120 \\
9 & 11 & 11 & 121 & 121 & 121 \\
10 & 10 & 12 & 100 & 144 & 120 \\
11 & 9 & 12 & 81 & 144 & 108 \\
12 & 11 & 12 & 121 & 144 & 144 \\
\hline & 132 & 137 & 1462 & 1571 & 1518 \\
\hline
\end{tabular}

Sumber : Data diolah, 2012

Diketahui :

$\begin{array}{ll}\mathrm{N} & =12 \\ \mathrm{X} & =132 \\ \mathrm{Y} & =137\end{array}$
$\mathrm{X}^{2}=1462$

$\mathrm{Y}^{2} \quad=1571$

$\mathrm{XY}=1518$ 
Kemudian langkah selanjutnya adalah mengoperasikan nilai-niai tersebut ke dalam rumus statistic product moment sebagai berikut :

$$
\begin{aligned}
& r \\
& =\frac{\mathrm{n}\left(\sum X Y\right)-\left(\sum X\right)\left(\sum Y\right)}{\sqrt{\left\{n \cdot \sum x^{2}-\left(\sum X\right)^{2}\right\} \cdot\left\{n \cdot \sum y^{2}-\left(\sum Y\right)^{2}\right\}}} \\
& r \\
& r \\
& =\frac{12 \cdot(1518)-(132)(137)}{\sqrt{\left\{12.1462-(132)^{2}\right\} \cdot\left\{12.1571-(137)^{2}\right\}}} \\
& \sqrt{\{17544-17424\} \cdot\{18852-18769\}}
\end{aligned}
$$

$$
\begin{gathered}
r=\frac{62}{\sqrt{\{120\} \cdot\{83\}}} \\
r=\frac{62}{\sqrt{9960}} \\
r=\frac{62}{99,7997} \\
r=0,621244352=0,621
\end{gathered}
$$

(pembulatan tiga angka dibelakang koma)

Dengan demikian diketahui bahwa nilai korelasi product moment adalah sebesar 0,621 setelah dikonfirmasikan dengan table interpretasi berada dalam tingkat ke-eratan tinggi.

TABEL NILAI r PRODUCT MOMENT

\begin{tabular}{|c|c|c|c|c|c|}
\hline \multirow{2}{*}{ No. } & \multicolumn{2}{|c|}{ Taraf Signifikan } & \multirow{2}{*}{ Taraf Signifikan } \\
\cline { 2 - 3 } \cline { 5 - 6 } & $\mathbf{5 \%}$ & $\mathbf{1 \%}$ & $\mathbf{N o}$ & $\mathbf{5 \%}$ & $\mathbf{1 \%}$ \\
\hline 7 & 0,754 & 0,874 & 40 & 0,312 & 0,403 \\
\hline 8 & 0,707 & 0,834 & 41 & 0,308 & 0,398 \\
\hline 9 & 0,666 & 0,798 & 42 & 0,304 & 0,939 \\
\hline 10 & 0,632 & 0,675 & 43 & 0,301 & 0,398 \\
\hline 11 & 0,602 & 0,735 & 44 & 0,297 & 0,384 \\
\hline 12 & 0,576 & 0,708 & 45 & 0,294 & 0,380 \\
\hline 13 & 0,553 & 0,684 & 46 & 0,291 & 0,376 \\
\hline 14 & 0,532 & 0,661 & 47 & 0,288 & 0,372 \\
\hline 15 & 0,514 & 0,641 & 48 & 0,284 & 0,368 \\
\hline 16 & 0,497 & 0,623 & 49 & 0,281 & 0,364 \\
\hline 17 & 0,482 & 0,606 & 50 & 0,297 & 0,361 \\
\hline 18 & 0,468 & 0,590 & 55 & 0,266 & 0,345 \\
\hline 19 & 0,456 & 0,575 & 60 & 0,254 & 0,330 \\
\hline 20 & 0,444 & 0,561 & 65 & 0,244 & 0,317 \\
\hline 21 & 0,433 & 0,549 & 70 & 0,235 & 0,306 \\
\hline 22 & 0,423 & 0,573 & 75 & 0,227 & 0,296 \\
\hline 23 & 0,413 & 0,526 & 80 & 0,220 & 0,286 \\
\hline 24 & 0,404 & 0,515 & 85 & 0,213 & 0,278 \\
\hline 25 & 0,396 & 0,505 & 90 & 0,207 & 0,270 \\
\hline 26 & 0,388 & 0,496 & 95 & 0,202 & 0,263 \\
\hline 27 & 0,381 & 0,487 & 100 & 0,195 & 0,256 \\
\hline 28 & 0,374 & 0,478 & 125 & 0,176 & 0,230 \\
\hline 29 & 0,367 & 0,470 & 150 & 0,159 & 0,210 \\
\hline
\end{tabular}




\begin{tabular}{|l|l|l|l|l|l|}
\hline 30 & 0,361 & 0,463 & 175 & 0,148 & 0,194 \\
\hline 31 & 0,355 & 0,456 & 200 & 0,138 & 0,181 \\
\hline 32 & 0,349 & 0,449 & 300 & 0,133 & 0,148 \\
\hline 33 & 0,344 & 0,442 & 400 & 0,098 & 0,128 \\
\hline 34 & 0,339 & 0,436 & 500 & 0,088 & 0,155 \\
\hline 35 & 0,344 & 0,430 & 600 & 0,030 & 0,105 \\
\hline 36 & 0,329 & 0,424 & 700 & 0,074 & 0,097 \\
\hline 37 & 0,325 & 0,418 & 800 & 0,070 & 0,091 \\
\hline 38 & 0,320 & 0,413 & 900 & 0,065 & 0,086 \\
\hline 39 & 0,316 & 0,408 & 1000 & 0,062 & 0,081 \\
\hline
\end{tabular}

Sumber : Metodologi Research, Sutrisno Hadi

TABEL NILAI UNTUK DISTRIBUSI $t$

\begin{tabular}{|l|l|l|l|l|l|l|l|l|l|l|}
\hline No. & To.995 & To.99 & To.975 & To.95 & To.90 & To.80 & To.75 & To.70 & To.60 & To.55 \\
\hline 1 & 93,66 & 31,82 & 12,71 & 6,31 & 3.08 & 1,376 & 1000 & 0,727 & 0,325 & 0,158 \\
\hline 2 & 9,25 & 6,95 & 4,30 & 2,92 & 1,89 & 1,061 & 0,816 & 0,617 & 0,289 & 0,142 \\
\hline 3 & 5,84 & 4,54 & 3,18 & 2,35 & 1,64 & 0,978 & 0,965 & 0,584 & 0,277 & 0,137 \\
\hline 4 & 4,60 & 3,75 & 2,78 & 2,13 & 1,53 & 0,941 & 0,741 & 0,569 & 0,271 & 0,134 \\
\hline & & & & & & & & & & \\
\hline 5 & 4,03 & 3,36 & 2,75 & 2,02 & 1,48 & 0,920 & 0,727 & 0,559 & 0,267 & 0,132 \\
\hline 6 & 3,71 & 3,14 & 2,45 & 1,94 & 1,44 & 0,906 & 0,718 & 0,553 & 0,265 & 0,131 \\
\hline 7 & 3,50 & 3,00 & 2,36 & 1,90 & 1,42 & 0,986 & 0,711 & 0,549 & 0,263 & 0,130 \\
\hline 8 & 3,36 & 2,90 & 2,31 & 1,86 & 1,40 & 0,889 & 0,706 & 0,546 & 0,262 & 0,130 \\
\hline 9 & 3,25 & 2,82 & 2,26 & 1,83 & 1,38 & 0,883 & 0,703 & 0,543 & 0,261 & 0,129 \\
\hline & & & & & & & & & & \\
\hline 10 & 3,17 & 2,76 & 2,23 & 1,81 & 1,37 & 0,879 & 0,700 & 0,542 & 0,260 & 0,129 \\
\hline 11 & 3,11 & 2,72 & 2,20 & 1,80 & 1,36 & 0,876 & 0,697 & 0,540 & 0,260 & 0,129 \\
\hline 12 & 3,06 & 2,68 & 2,18 & 1,78 & 1,36 & 0,873 & 0,695 & 0,539 & 0,259 & 0,128 \\
\hline 13 & 3,01 & 2,65 & 2,16 & 1,77 & 1,35 & 0,870 & 0,694 & 0,538 & 0,259 & 0,128 \\
\hline 14 & 3,98 & 2,62 & 2,14 & 1,76 & 1,34 & 0,868 & 0,692 & 0,537 & 0,258 & 0,128 \\
\hline 15 & 2,95 & 2,60 & 2,13 & 1,75 & 1,34 & 0,866 & 0,691 & 0,536 & 0,258 & 0,128 \\
\hline 16 & 2,92 & 2,58 & 2,12 & 1,75 & 1,34 & 0,865 & 0,690 & 0,535 & 0,258 & 0,128 \\
\hline 17 & 2,90 & 2,57 & 2,11 & 1,74 & 1,33 & 0,863 & 0,689 & 0,535 & 0,257 & 0,128 \\
\hline 18 & 2,88 & 2,55 & 2,10 & 1,73 & 1,33 & 0,862 & 0,688 & 0,534 & 0,257 & 0,127 \\
\hline 19 & 2,86 & 2,54 & 2,09 & 1,73 & 1,33 & 0,861 & 0,688 & 0,533 & 0,257 & 0,127 \\
\hline & & & & & & & & & & \\
\hline 20 & 2,84 & 2,53 & 2,09 & 1,72 & 1,32 & 0,860 & 0,687 & 0,533 & 0,257 & 0,127 \\
\hline 21 & 2,83 & 2,52 & 2,08 & 1,72 & 1,32 & 0,859 & 0,686 & 0,532 & 0,257 & 0,127 \\
\hline 22 & 2,82 & 2,51 & 2,07 & 1,72 & 1,32 & 0,858 & 0,686 & 0,532 & 0,256 & 0,127 \\
\hline 23 & 2,81 & 2,50 & 2,07 & 1,71 & 1,32 & 0,858 & 0,685 & 0,532 & 0,256 & 0,127 \\
\hline 24 & 2,80 & 2,49 & 2,06 & 1,71 & 1,32 & 0,857 & 0,685 & 0,531 & 0,256 & 0,127 \\
\hline & & & & & & & & & & \\
\hline 25 & 2,79 & 2,48 & 2,06 & 1,71 & 1,32 & 0,856 & 0,684 & 0,531 & 0,256 & 0,127 \\
\hline
\end{tabular}




\begin{tabular}{|l|l|l|l|l|l|l|l|l|l|l|}
\hline 26 & 2,78 & 2,48 & 2,06 & 1,71 & 1,32 & 0,856 & 0,684 & 0,531 & 0,256 & 0,127 \\
\hline 27 & 2,77 & 2,47 & 2,05 & 1,70 & 1,31 & 0,855 & 0,684 & 0,531 & 0,256 & 0,127 \\
\hline 28 & 2,76 & 2,47 & 2,05 & 1,70 & 1,31 & 0,855 & 0,683 & 0,530 & 0,256 & 0,127 \\
\hline 29 & 2,76 & 2,46 & 2,04 & 1,70 & 1,31 & 0,854 & 0,683 & 0,530 & 0,256 & 0,127 \\
\hline & & & & & & & & & & \\
\hline 30 & 2,75 & 2,46 & 2,04 & 1,70 & 1,31 & 0,854 & 0,683 & 0,530 & 0,256 & 0,127 \\
\hline & & & & & & & & & & \\
\hline 40 & 2,70 & 2,42 & 2,02 & 1,68 & 1,30 & 0,854 & 0,681 & 0,529 & 0,255 & 0,126 \\
\hline & & & & & & & & & & \\
\hline 60 & 2,66 & 2,39 & 2,00 & 1,67 & 1,30 & 0,848 & 0,679 & 0,527 & 0,254 & 0,126 \\
\hline & & & & & & & & & & \\
\hline 120 & 2,62 & 2,36 & 1,98 & 1,66 & 1,29 & 0,845 & 0,677 & 0,526 & 0,254 & 0,126 \\
\hline- & 2,58 & 2,33 & 1,96 & 16,45 & 1,28 & 0,842 & 0,674 & 0,523 & 0,253 & 0,126 \\
\hline
\end{tabular}

Sumber : Metode Statistik, Sudjana

Tabel Interpretasi nilai $r$

\begin{tabular}{|c|c|}
\hline $\begin{array}{c}\text { Interval } \\
\text { Nilai } \boldsymbol{r}\end{array}$ & $\begin{array}{c}\text { Ke-eratan/kekuatan } \\
\text { Hubungan }\end{array}$ \\
\hline $0,81-1,00$ & Sangat Tinggi \\
\hline $0,61-0,80$ & Tinggi \\
\hline $0,81-0,60$ & Sedang \\
\hline $0,21-0,40$ & Rendah \\
\hline $0,00-0,20$ & Sangat Rendah \\
\hline
\end{tabular}

Kemudian untuk mengetahui keeratan peranan pengendalian tata usaha menunjang kelancaran tugas ditentukan oleh factor penentu yaitu $\mathrm{r}^{2}$ x $100\left(0,621^{2} \mathrm{x}\right.$ $100=0,385641 \times 100=38,5641)$ dibulatkan menjadi $38 \%$.

\section{Uji Hipotesis}

Berdasarkan hasil perhitungan tersebut, berarti peranan pengendalian tata usaha terhadap kelancaran tugas pegawai sebesar 0,38 atau $38 \%$. Selanjutnya untuk menguji hipotesis, penulis (diterima atau ditolak), maka penulis menggunakan rumus Uji t, dengan ketentuan sebagai berikut :

a. Ho ditolak jika $t$ hitung, lebih besar dari pada tabel $\mathrm{t}_{\text {table }}\left(\mathrm{H}_{1}\right.$ diterima)

b. Ho ditolak jika $t$ hitung lebih kecil dari pada tabel $\mathrm{t}_{\text {tabel }}\left(\mathrm{H}_{1}\right.$ ditolak)
Pengoperasian uji $\mathrm{t}$ adalah sebagai berikut :

$$
\begin{gathered}
t=\frac{\mathrm{r} \sqrt{n-2}}{\sqrt{l-r^{2}}} \\
t=\frac{0,621 \sqrt{12-2}}{\sqrt{l-0,621^{2}}} \\
t=\frac{0,621 \sqrt{10}}{\sqrt{l-0,385641}} \\
t=\frac{0,621 \times 3,16227766}{\sqrt{0,614359}} \\
t=\frac{1,96377442686}{0,78381056} \\
t=2,5054197
\end{gathered}
$$

$t=2,505$ (pembulatan tiga angka dibelakang koma)

Hasil perhitungan di atas, diperoleh nilai $\mathrm{t}$ hitung sebesar 2,505. Setelah dikonfirmasi dengan $t$ tabel pada derajat penyimpangan (alpa) 5\% dan derajat kebebasan $\mathrm{n}-2=(12-2)=10$, terdapat nilai $\mathrm{t}$ tabel sebesar 1,812, ini berari t hitung lebih besar dari $t$ tabel. Dengan demikian hipotesis penulis peran pengendalian tata usaha berjalan efektif dalam menunjang 
kelancaran tugas SDN 1 Way Gubak Kecamatan Panjang Kota Bandar Lampung diterima.

\section{KESIMPULAN}

Berdasarkan hasil penelitian dan pembahasan yang telah penulis lakukan, maka penulis dapat menarik kesimpulan sebagai berikut :

1. Kegiatan Tata Usaha adalah merupakan suatu pengelompokan kegiatan-kegiatan administrasi yang sejenis berdasarkan sifat dan bentuk pelaksanaannya.

2. Pengendalian Tata Usaha pada SDN 1 Way Gubak Kecamatan Panjang Kota Bandar Lampung adalah dalam kategori baik, ini berarti kegiatan ketatausahaan telah dilaksanakan secara baik dengan prosedur yang tepat, proses yang cepat, melalui kerjasama dan sesuai aturan. Hal ini terlihat pada tabel 5 (distribusi kumulatif jawaban responden mengenai variabel $\mathrm{X}$ ).

3. Kelancaran pelaksanaan tugas pada SDN 1 Way Gubak Kecamatan Panjang Kota Bandar Lampung adalah dalam kategori baik, ini berarti penyelesaian tugas cepat dan tepat, sesuatu aturan dan bertanggung jawab. Hal ini dapat dilihat pada tabel 10 (distribusi kumulatif jawaban responden mengenai variabel Y).

\section{DAFTAR PUSTAKA}

Abdurahman Arifin, 2001, Leadership, Teori Pembangaman danFilsafat Kepemimpinan Kerja, Ekarata.

Atmosudirdjo Prajudi, 1989, Dasar-Dasar Ilmu Administrasi, Seri Pustaka, Jakarta.
Gie, The Liang, 2000, Administrasi Perkantoran Modern, PD. Radya Indira, Yogyakarta.

Handayaningrat Sarwono, Drs., 2002, Pengantar Studi Ilmu Administrani dan Manajemen, Gunung Agung, Jakarta.

Islami Irfan, M., 2004, Prinsip-Prinsip Perumusan Kebijakan, Bina Aksara, Jakarta

Kartono Kartini, 2000, Pemimpin dan Kepemimpinan, Rajawali Pers, Jakarta.

K. Soekarno, Drs., 1999, Dasar-Dasar Manajemen, Miswar, Jakarta.

Mamullang, M., Drs., 2001, Manajemen Personalia, Ghalia Indonesia, Jakarta.

Nawawi Harar, H., 2000, Metode Penelitian Bidang Sosial, Gajah Mada University Pers, Yogyakarta.

Pamudji, S., 2002, Kepemimpinan Pemerintahan di Indonesia, Bina Aksara, Jakarta.

Poerwadarminta W.J.S., 2002, Kamus Umum Bahasa Indonesia, PN Balai Pustaka, Jakarta.

Sarwoto, Drs., 2001, Dasar-Dasar Organisasi dan Manajemen, Ghalia Indonesia, Jakarta.

Siagian, S.P, DR. MPA., 2001, Filsafat Adminstrasi, Gunung Agung, Jakarta.

Silalahi Oberlin, 2000, Beberapa Aspek Kebijaksanaan Negara, Liberty, Yogyakarta.

Tjokroamijojo Bintaro, 1987, Pengantar Administrasi Pembangunan, LPPPES, Jakarta,

Wahab Abdul Solihin, 2002, Pengantar Analisis Kebijaksanaan Negara, Rineka Cipta, Jakarta.

Westa Pariatra, 2003, Ensiklopedia Administrasi, CV. Haji Masagung, Jakarta. 